\title{
Is Genetic Screening Necessary for Determining the Possibility of Venous Thromboembolism in Cancer Patients?
}

\author{
Ece Onur $^{\mathrm{a}} \quad$ Adnan Taner Kurdal $^{\mathrm{b}}$ Berrin Tugrul ${ }^{\mathrm{d}}$ Ihsan Iskesen ${ }^{\mathrm{b}}$ Pınar Dundar ${ }^{\mathrm{c}}$ \\ Fatma Taneli $^{\mathrm{a}}$ Cevval Ulman ${ }^{\mathrm{a}}$ Ahmet Var $^{\mathrm{a}}$ \\ Departments of a Biochemistry, ${ }^{b}$ Cardiovascular Surgery and ${ }^{\mathrm{C} P u b l i c}$ Health, Celal Bayar University School of \\ Medicine, and d Department of Molecular Biology, Celal Bayar University School of Science and Literature, \\ Manisa, Turkey
}

\section{Key Words}

Venous thromboembolism • Cancer $\cdot$ Mutation •

Polymorphism

\begin{abstract}
Objective: To determine the risk of an association with some genetic polymorphisms involved in venous thromboembolism (VTE) gene variations (FVL, FV H1299R, Fll G20210A, MTHFR C677T, MTHFR A1298C, PAI-1 4G/5G, $\beta$-fibrinogen -455 G $\rightarrow$ A, FXIII Val34Leu and Gpllla HPA-1a) in cancer patients. Subjects and Methods: Among 78 cancer patients, 28 who had proven first episode of VTE were selected as the patient group, with 50 control samples selected from age-, sex- and body mass index-matched healthy volunteers (healthy group). The differences in frequency of genetic polymorphisms were found to be statistically insignificant between these two groups. Results: Logistic regression analysis after adjustment for age, sex, smoking and hypertension showed no difference. The screened mutations of these genes were not significantly associated with VTE risk. Conclusion: There is no possible benefit from genetic screening tests regarding VTE in cancer patients.
\end{abstract}

Copyright $\odot 2011$ S. Karger AG, Base
(C) 2011 S. Karger AG, Basel

$1011-7571 / 12 / 0212-0160 \$ 38.00 / 0$

Fax +41613061234 E-Mail karger@karger.ch www.karger.com
Accessible online at:

www.karger.com/mpp

\section{Introduction}

Venous thromboembolism (VTE) is a multifactorial disease, and the mechanisms contributing to this phenomenon include the classical Virchow triad: hypercoagulable states, stasis and endothelial damage [1]. In addition to well-established, acquired risk factors for VTE, over the past decades, several lines of evidence emerged, pointing to a role of genetic risk factors mainly related to the hemostatic system, influencing thrombosis risk $[2,3]$.

The relationships between malignant diseases and VTE lead to well-recognized complications of cancer [4, 5] as the increased risk of VTE develops in advanced disease, being influenced by increased tumor cell burden, by immobilization due to tumor cachexia or pathologic fractures, and by mechanical compression of the veins by the tumor mass $[6,7]$. However, the contribution of preexisting hereditary risk factors to the occurrence of venous thrombosis in cancer patients has not yet been widely studied [8]. During the last few years, major advances have been made in our understanding of the contribution of genetic factors to the risk of VTE [4].

In this study, therefore, we aimed to determine the risk of an association of VTE in cancer patients with some genetic polymorphisms that have frequently been report-

Dr. Adnan Taner Kurdal

Celal Bayar Universitesi

Tip Fakultesi Kalp Damar Cerrahisi ABD

TR- 45010 Manisa (Turkey)

Tel. +90236235 0675, E-Mail doktoratk@ hotmail.com 
Table 1. Demographic data on the study participants

\begin{tabular}{llll}
\hline Parameters & Cases $(\mathrm{n}=28)$ & Controls $(\mathrm{n}=50)$ & $\mathrm{p}$ \\
\hline Male sex & $17(60.7 \%)$ & $32(64.0 \%)$ & NS \\
Age, years & $52.6 \pm 10.3$ & $51.6 \pm 9.6$ & NS \\
BMI, kg/m ${ }^{2}$ & $23.6 \pm 2.3$ & $23.3 \pm 2.4$ & NS \\
Smoking & $53.5 \%$ & $52.0 \%$ & NS \\
Hypertension $^{\mathrm{a}}$ & $32.1 \%$ & $28.0 \%$ & NS \\
Dyslipidemia $^{\mathrm{b}}$ & $8(28.5 \%)$ & $13(26.0 \%)$ & NS \\
\hline
\end{tabular}

$\mathrm{BMI}=$ Body mass index.

a $\geq 140 \mathrm{~mm} \mathrm{Hg}$. ${ }^{\mathrm{b}}$ Total cholesterol: $\geq 150 \mathrm{mg} / \mathrm{dl}$; LDL cholesterol: $\geq 130 \mathrm{mg} / \mathrm{dl}$; HDL cholesterol: $\leq 40 \mathrm{mg} / \mathrm{dl}$; triglyceride: $\geq 150 \mathrm{mg} / \mathrm{dl}$.

ed: factor V Leiden (FVL) [6]; factor V R2 (FV H1299R) [9]; the prothrombin G20210A mutation (FII G20210A) [6]; the C667T mutation in the 5,10-methylenetetrahydrofolate reductase gene (MTHFR C677T) $[6,8]$; the A1298C mutation in the MTHFR gene (MTHFR A1298C) [10]; the $4 \mathrm{G} / 5 \mathrm{G}$ sequence polymorphism in the promoter of plasminogen activator inhibitor-1 gene (PAI-1 4G/5G) [11]; the $G \rightarrow$ A transition at the nucleotide $-455 \beta$-chain of fibrinogen ( $\beta$-fibrinogen $-455 \mathrm{G} \rightarrow \mathrm{A}$ ); the $\mathrm{G} \rightarrow \mathrm{T}$ transition in exon 2 of the coagulation factor XIII A-subunit gene (FXIII Val34Leu) [6], and the substitution of proline for leucine (Leu33Pro) [12] in the glycoprotein IIIa gene (GpIIIa HPA-1a) [10].

\section{Subjects and Methods}

This study was performed at Celal Bayar University, Manisa, Turkey. The institutional ethics committee approved the research proposal, and all patients and control subjects provided written informed consent in accordance with the Declaration of Helsinki. Among a total of 78 subjects, 28 cancer patients who had their first proven episode of VTE were selected for the patient group. This group was compared with 50 healthy volunteers (healthy group) who were matched for age, sex and body mass index. The VTE diagnosis was made clinically and confirmed by color Doppler ultrasonography, phlebography or ventilation/perfusion scan.

\section{Blood Collection and DNA Analysis}

Blood was withdrawn from the antecubital vein into three Vacutainer ${ }^{\circledR}$ tubes (CTAD and EDTA; Becton Dickinson) and separated into plasma and red cells by centrifugation at 3,000 rpm. DNA was extracted from white blood cells using the QIAamp DNA Blood Mini Kit (Qiagen, Hilden, Germany), and stored at $-80^{\circ} \mathrm{C}$ for later use. The investigators who performed the determinations were blinded as to which group the sample was taken from. The following nine polymorphisms of genes encoding proteins involved in blood coagulation, platelet function and fibrinolysis were analyzed: FVL, FV H1299R, FII G20210A, MTHFR C677T, MTHFR A1298C, PAI-1 4G/5G, $\beta$-fibrinogen $-455 \mathrm{G} \rightarrow \mathrm{A}$, FXIII Val34Leu and GpIIIa HPA-1a.

Polymerase Chain Reaction (PCR) and Reverse Hybridization

The CVD Strip Assay (Vienna Lab, Austria) was used to detect the previously described polymorphisms of genes encoding proteins involved in blood coagulation, platelet function and fibrinolysis. The protocol was followed exactly as described by the manufacturer. In summary, the procedure included three steps: DNA isolation, PCR amplification, and hybridization of amplification products. The different gene sequences including the nine mutations/polymorphisms were simultaneously amplified in vitro and biotin labeled in two parallel PCR (multiplexing). The amplification program included an initial denaturation step of $94^{\circ} \mathrm{C}$ for $2 \mathrm{~min}$, followed by $35 \mathrm{cycles}$ of $94^{\circ} \mathrm{C}$ for $15 \mathrm{~s}, 58^{\circ} \mathrm{C}$ for $30 \mathrm{~s}, 72^{\circ} \mathrm{C}$ for $30 \mathrm{~s}$, and a final extension step of $72^{\circ} \mathrm{C}$ for $3 \mathrm{~min}$. The amplification products were selectively hybridized to a test strip which contained allele-specific oligonucleotide (short segment of DNA) probes immobilized as an array of parallel lines. Hybridization was carried out for $30 \mathrm{~min}$ at $45^{\circ} \mathrm{C}$ in a shaking water bath. After 3 stringent washes at $45^{\circ} \mathrm{C}$, bound biotinylated PCR fragments were detected using a streptavidin-alkaline phosphatase conjugate and color substrates. Upon positive reaction, a purple staining was visible after $15 \mathrm{~min}$ [13].

\section{Statistical Analysis}

To assess the association between genotype and VTE, univariate and multivariate (by using the logistic regression model) odds ratios (OR) with 95\% confidence intervals (CI) were calculated. Fisher's exact test was used to compare demographic data between the control and study groups. Statistical significance was defined as two-tailed $\mathrm{p}<0.05$. All statistical analysis was performed with SPSS for Windows (version 11.0; SPSS, Chicago, Ill., USA).

\section{Results}

Demographic data of all participants are given in table 1 . There was no difference in parameters between the two groups. The distributions of hemostatic gene polymorphisms in the study group and the control group are shown in table 2 . No homozygote mutant alleles were found for FVL, FV H1299R, FII G20210A and FXIII Val34Leu in both groups. The differences in frequency of the genetic polymorphisms were statistically insignificant between the study group and the control group ( $\mathrm{p}>$ 0.05). Logistic regression analysis after adjustment for age, sex, smoking and hypertension also did not show any difference. The genotypes of the FVL, FV H1299R, FII G20210A, MTHFR C677T, MTHFR A1298C, PAI-1 4G/5G, $\beta$-fibrinogen $-455 \mathrm{G} \rightarrow \mathrm{A}$, FXIII Val34Leu and GpIIIa HPA-1a genes were not significantly associated with VTE risk. 
Table 2. Gene polymorphism prevalence and risk of developing VTE

\begin{tabular}{|c|c|c|c|c|}
\hline & $\begin{array}{l}\text { Cases, \% } \\
(\mathrm{n}=28)\end{array}$ & $\begin{array}{l}\text { Controls, \% } \\
(\mathrm{n}=50)\end{array}$ & Univariate OR & Multivariate OR \\
\hline \multicolumn{5}{|l|}{ FVL } \\
\hline $0 / 0$ & $92.9(\mathrm{n}=26)$ & $94(\mathrm{n}=47)$ & 1 & 1 \\
\hline $0 / 1$ & $7.1(\mathrm{n}=2)$ & $6(n=3)$ & $0.8(0.27-11.24)$ & $0.74(0.19-8.89)$ \\
\hline \multicolumn{5}{|l|}{ FV H1299R } \\
\hline $0 / 0$ & $79.6(n=22)$ & $84(\mathrm{n}=42)$ & 1 & 1 \\
\hline $0 / 1$ & $21.4(\mathrm{n}=6)$ & $16(\mathrm{n}=8)$ & $1.32(0.38-2.00)$ & $2.00(0.40-8.78)$ \\
\hline \multicolumn{5}{|c|}{ FII G20210A } \\
\hline $0 / 0$ & $96.5(n=26)$ & $98(n=49)$ & 1 & 1 \\
\hline $0 / 1$ & $3.5(\mathrm{n}=2)$ & $2(\mathrm{n}=1)$ & $1(0.38-44.7)$ & $1.68(0.46-32.5)$ \\
\hline \multicolumn{5}{|c|}{ MTHFR C677T } \\
\hline $0 / 0$ & $50.0(\mathrm{n}=14)$ & $56(n=28)$ & $1.32(0.36-4.8)$ & $2.06(0.43-8.92)$ \\
\hline $0 / 1$ & $32.1(\mathrm{n}=9)$ & $28(\mathrm{n}=14)$ & $1.54(0.56-5.3)$ & $2.68(0.68-8.99)$ \\
\hline $1 / 1$ & $17.9(\mathrm{n}=5)$ & $16(\mathrm{n}=8)$ & $1.45(0.47-4.9)$ & $2.43(0.59-7.24)$ \\
\hline \multicolumn{5}{|c|}{ MTHFR A1298C } \\
\hline $0 / 0$ & $46.4(\mathrm{n}=13)$ & $44(\mathrm{n}=22)$ & 1 & 1 \\
\hline $0 / 1$ & $39.3(\mathrm{n}=11)$ & $44(\mathrm{n}=22)$ & $1.33(0.78-34.6)$ & $1(0.97-34.8)$ \\
\hline $1 / 1$ & $14.3(\mathrm{n}=4)$ & $12(\mathrm{n}=6)$ & 1 & 1 \\
\hline \multicolumn{5}{|c|}{ PAI-1 4G/5G } \\
\hline $4 \mathrm{G} / 4 \mathrm{G}$ & $21.4(\mathrm{n}=6)$ & $28(\mathrm{n}=14)$ & $0.33(0.04-1.21)$ & $1.27(0.03-2.34)$ \\
\hline $4 \mathrm{G} / 5 \mathrm{G}$ & $35.7(\mathrm{n}=10)$ & $38(\mathrm{n}=19)$ & $0.78(0.56-2.67)$ & $0.93(0.68-3.65)$ \\
\hline $5 \mathrm{G} / 5 \mathrm{G}$ & $42.9(\mathrm{n}=12)$ & $34(\mathrm{n}=17)$ & $2.04(0.80-4.78)$ & $2.02(0.65-6.79)$ \\
\hline \multicolumn{5}{|c|}{$\beta$-Fibrinogen $-455 \mathrm{G} \rightarrow \mathrm{A}$} \\
\hline $0 / 0$ & $50.0(\mathrm{n}=14)$ & $52(\mathrm{n}=26)$ & 1 & 1 \\
\hline $0 / 1$ & $39.3(\mathrm{n}=11)$ & $38(\mathrm{n}=19)$ & 1 & 1 \\
\hline $1 / 1$ & $10.7(\mathrm{n}=3)$ & $10(\mathrm{n}=5)$ & 1 & 1 \\
\hline \multicolumn{5}{|c|}{ FXIII Val34Leu } \\
\hline $0 / 0$ & $82.1(\mathrm{n}=23)$ & $64(\mathrm{n}=32)$ & $0.91(0.36-2.54)$ & $0.76(0.24-2.14)$ \\
\hline $0 / 1$ & $17.9(\mathrm{n}=5)$ & $36(\mathrm{n}=18)$ & $1.56(0.52-4.62)$ & $2.30(0.58-9.60)$ \\
\hline \multicolumn{5}{|c|}{ GpIIIa HPA-1a } \\
\hline $\mathrm{a} / \mathrm{b}$ & $25(\mathrm{n}=7)$ & $24(\mathrm{n}=12)$ & 1 & 1 \\
\hline $\mathrm{a} / \mathrm{a}$ & $75(\mathrm{n}=21)$ & $76(\mathrm{n}=38)$ & 1 & 1 \\
\hline
\end{tabular}

Values in parentheses denote 95\% CI unless indicated otherwise. Genotype frequencies in cases and controls, univariate and multivariate OR. $0 / 0=$ Genotype associated with the presence of 2 wild-type alleles; $0 / 1=$ presence of 1 wild-type and 1 mutant allele; $1 / 1$ = presence of 2 mutant alleles.

\section{Discussion}

Similar frequencies of the gene polymorphisms of FVL, FV H1299R, FII G20210A, MTHFR C677T, MTHFR A1298C, PAI-1 4G/5G, $\beta$-fibrinogen -455 G $\rightarrow$ A, FXIII Val34Leu and GpIIIa HPA-1a were observed in cancer and healthy subjects. Therefore, the findings of this study do not point to an association between these nine polymorphisms and risk of VTE in cancer patients.

The most widely reported, inherited thrombophiliarelated mutation in cancer patients is the FVL mutation $[12,14,15]$. Although activated protein $C$ resistance due to FVL mutation is a frequent cause of VTE, some authors have reported that the FVL mutation does not play a ma- jor role in the hypercoagulable state of cancer $[16,17]$ as in our study.

A recent study showed that FVL mutation was not associated with increased risk of thrombosis, but that FII G20210A was suggested as a factor contributing to the development of VTE in cancer patients [16]. Conversely, Eroglu et al. [18] observed that FII G20210A polymorphism was not related to increased risk of VTE. In one prospective study, the prevalence and clinical significance of four gene variations (FVL, FII G20210A, FXIII MTHFR C677T and Val34Leu) were evaluated in cancer patients, with and without VTE. No associations between these four polymorphisms and risk of VTE were observed [6]. There were no significant differences in the preva- 
lence of the nine polymorphisms analyzed in our investigation between the group of cancer patients with VTE and the control group. The present data confirmed that the FVL, FII G20210A, MTHFR C677T and FXIII Val34Leu mutations are not determinants of thrombotic risk in cancer.

Limitations of our study include the fact that the sample was too small to have enough statistical power to obtain sufficiently narrow CI. Equally important, unequal numbers of cancer patients with VTE $(\mathrm{n}=28)$ and healthy subjects without VTE $(n=50)$ were enrolled in the study. This study shows that establishment of the risk in association with some genetic polymorphisms involved in VTE, and of the potential benefit from screening for this condition in patients with cancer, remains imprecise. The relationship between cancer, coagulation and thrombosis is a very complex issue that deserves further study in larger series.

\section{Conclusion}

Our findings show that frequencies of the nine gene polymorphism were observed in both cancer and healthy subjects. Therefore, there was no association between these polymorphisms and the risk of developing VTE in cancer patients. Hence, there will be no potential benefit from screening for these genes in cancer patients.

\section{Acknowledgment}

This study was supported by a grant from the Celal Bayar University Scientific Investigation Fund.

\section{References}

1 Blann AD, Lip GY: Virchow's triad revisited: the importance of soluble coagulation factors, the endothelium, and platelets. Thromb Res 2001;101:321-327.

2 de Stefano V, Finazzi G, Mannucci PM: Inherited thrombophilia: pathogenesis, clinical syndromes, and management. Blood 1996;87:3531-3544

- 3 Seligsohn U, Zivelin A: Thrombophilia as a multigenic disorder. Thromb Haemost 1997; 78:297-301.

4 Prandoni P, Piccioli A, Girolami A: Cancer and venous thromboembolism: an overview. Haematologica 1999;84:437-445.

5 Prandoni P: Antithrombotic strategies in patients with cancer. Thromb Haemost 1997; 78:141-144.

6 6 Donati MB, Falanga A: Pathogenetic mechanisms of thrombosis in malignancy. Acta Haematol 2001;106:18-24.

7 Gale AJ, Gordon SG: Update on tumor cell procoagulant factors. Acta Haematol 2001; 106:25-32.

8 Ramacciotti E, Wolosker N, Puech-Leao P, Zeratti EA, Gusson PR, del Giglio A, Franco RF: Prevalence of Factor V Leiden, FII G20210A, FXIII Val34Leu and MTHFR C677T polymorphisms in cancer patients with and without venous thrombosis. Thromb Res 2003;109:171-174.
9 Otrock ZK, Taher AT, Shamseddeen WA, Zaatari G, Bazarbachi A, Mahfouz RA: Factor V HR2 haplotype: a risk factor for venous thromboembolism in individuals with absence of Factor V Leiden. Ann Hematol 2008; 87:1013-1016.

10 Spiroski I, Kedev S, Antov S, Arsov T, Krstevska M, Dzhekova-Stojkova S, Bosilkova G, Kostovska S, Trajkov D, Petlichkovski A, Strezova A, Efinska-Mladenovska O, Spiroski M: Methylenetetrahydrofolate reductase (MTHFR-677 and MTHFR-1298) genotypes and haplotypes and plasma homocysteine levels in patients with occlusive artery disease and deep venous thrombosis. Acta Biochim Pol 2008;55:587-594.

11 Akhter M, Biswas A, Ranjan R, Meena A, Yadav B, Sharma A, Saxena R: Plasminogen activator inhibitor-1 (PAI-1) gene $4 \mathrm{G} / 5 \mathrm{G}$ promoter polymorphism is seen in higher frequency in the Indian patients with deep vein thrombosis. Clin Appl Thromb Hemost 2010;16:184-188.

12 Xenophontos SL, Hadjivassiliou M, Ayrton $\mathrm{N}$, Karagrigoriou A, Pantzaris M, Nicolaides AN, Cariolou MA: Spectrum and prevalence of prothrombotic single nucleotide polymorphism profiles in the Greek Cypriot population. Int Angiol 2002;21:322-329.
13 Var A, Utük O, Akçalıu S, Sanlıdag T, Uyanık BS, Dinç G: Impact of hemostatic gene single point mutations in patients with non-diabetic coronary artery disease. Mol Biol Rep 2009;36:2235-2243.

14 Decousus H, Moulin N, Quenet S, Bost V, Guillot KR, Laporte S, Mismetti P: Thrombophilia and risk of venous thrombosis in patients with cancer. Thromb Res 2007; 120(suppl 2):S51-S61.

15 Kennedy M, Andreescu AC, Greenblatt MS, Jiang H, Thomas CA, Chassereau L, Wong C, Durda P, Cushman M: Factor V Leiden, prothrombin 20210A and the risk of venous thrombosis among cancer patients. Br J Haematol 2005; 128:386-388.

16 Otterson GA, Monahan BP, Harold N, Steinberg SM, Frame JN, Kaye FJ: Clinical significance of the $\mathrm{FV}: \mathrm{Q}^{506}$ mutation in unselected oncology patients. Am J Med 1996;101:406412 .

17 Sifontes MT, Nuss R, Hunger SP, Wilimas J, Jacobson LJ, Manco-Johnson MJ: The Factor $\mathrm{V}$ Leiden mutation in children with cancer and thrombosis. Br J Haematol 1997; 96:484489.

18 Eroglu A, Ulu A, Cam R, Kurtman C, Akar N: Prevalence of Factor V 1691 G-A (Leiden) and prothrombin G20210A polymorphisms and the risk of venous thrombosis among cancer patients. J Thromb Thrombolysis 2007;23:31-34. 